\title{
Archivo Ana Victoria Jiménez del movimiento feminista en México (1970-1990)
}

El archivo de Ana Victoria Jiménez (Ciudad de México, 1941) documenta la historia del movimiento feminista en México a lo largo de dos décadas (de 1970 a 1990) a través de imágenes fotográficas, carteles, folletos, publicaciones periódicas y libros. Estos documentos son testimonios invaluables de la lucha de las feministas en favor de los derechos de las mujeres. Su sección fotográfica - considerada la más amplia y completa dedicada a este tema- es fruto de la activa participación de Ana Victoria Jiménez en este movimiento. Al mismo tiempo, en el archivo se resguardan materiales impresos de diversa índole, muchos de ellos de escasa circulación o de naturaleza efímera, como los volantes y los carteles, en los que se materializa la diversidad de sentires, posturas y demandas de los colectivos que se expresaron mediante ellos.

De las manifestaciones públicas en torno a su activismo feminista, Ana Victoria Jiménez resguardó materiales efímeros como carteles, panfletos y hojas volantes. Y al mismo tiempo, coleccionó y preservó diversas publicaciones fundamentales para la historia de la lucha feminista en el mundo y en México, como la revista FEM; ejemplares de diarios, folletería diversa y una biblioteca especializada en feminismo. El acervo está organizado en seis secciones con estas cantidades aproximadas en cada una: 4250 ítems documentales, 250 carteles, 300 folletos y agendas, 100 ejemplares de hemerografía, 3319 imágenes fotográficas y $\mathbf{5 5 0}$ volúmenes bibliográficos.

Ana Victoria Jiménez formó parte de diversos colectivos como la Unión Nacional de Mujeres Mexicanas, Mujeres en Acción Solidaria (MAS) y el grupo de arte feminista Tlacuilas y Retrateras. Colaboró con textos y fotografías en diversas publicaciones como FEM, Interviú y Siempre, entre otras. Como editora, ha estado al cargo de diversas publicaciones de grupos independientes e instituciones académicas como libros y manuales relacionadas con temas de la mujer.

El archivo que formó durante estos años documenta su propia obra en estos ámbitos, pero también registra ampliamente el trabajo colectivo del movimiento feminista, pues incorpora publicaciones y materiales informativos -muchos de ellos fruto de colaboraciones o anónimas-que forman un retrato muy completo de dicho movimiento. En él se cubren los aspectos legales, políticos y artísticos de la lucha feminista en nuestro país durante el último tercio del siglo XX.

Ana Victoria Jiménez donó personalmente su archivo a la Universidad Iberoamericana Ciudad de México en 2011, donde se puede consultar por todas y todos los investigadores e investigadoras interesadas.

POR LUIS HÉCTOR INCLÁN CIENFUEGOS. Coordinador de acervos históricos de la Biblioteca Francisco Xavier Clavigero, Universidad Iberoamericana, Ciudad de México. 

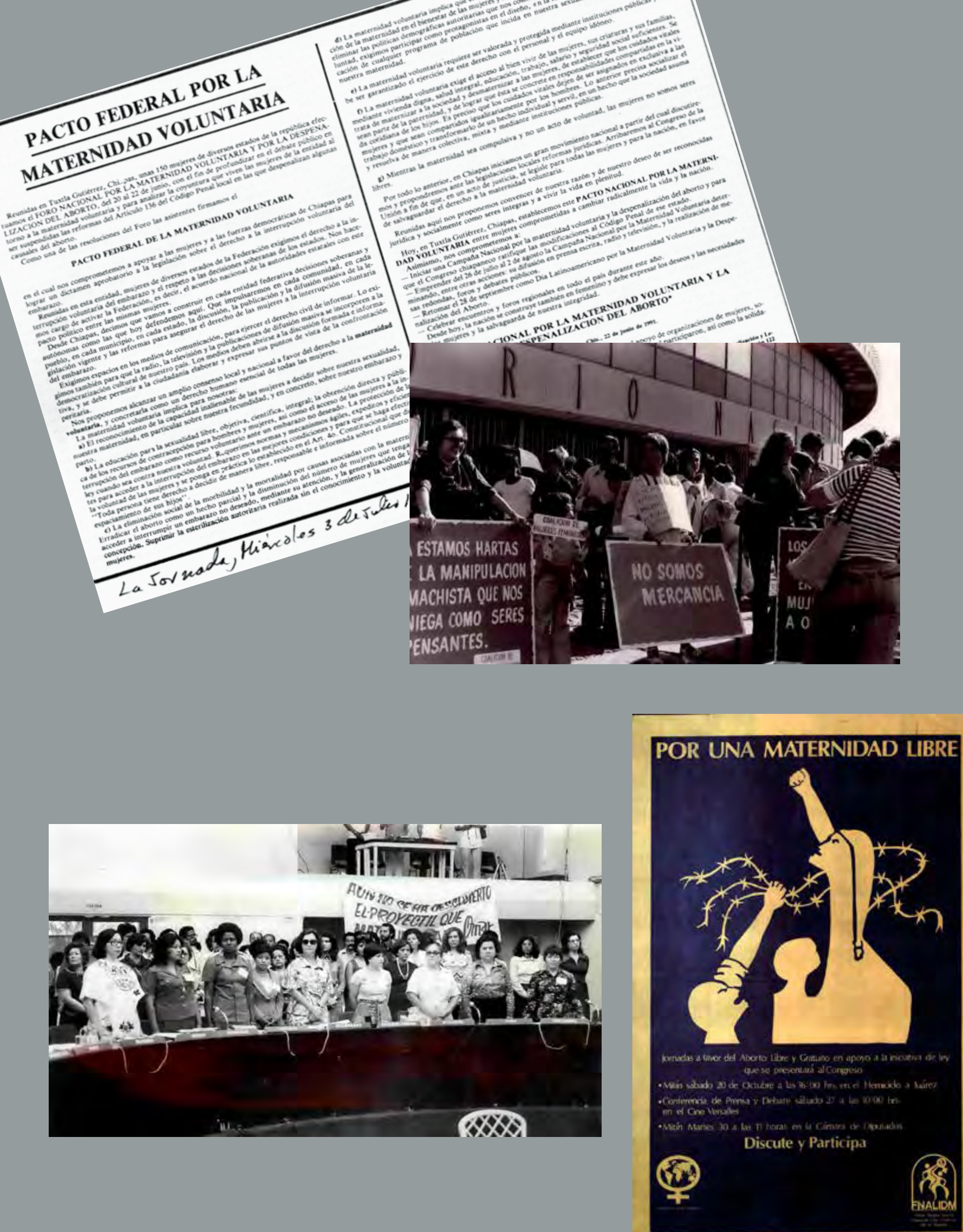


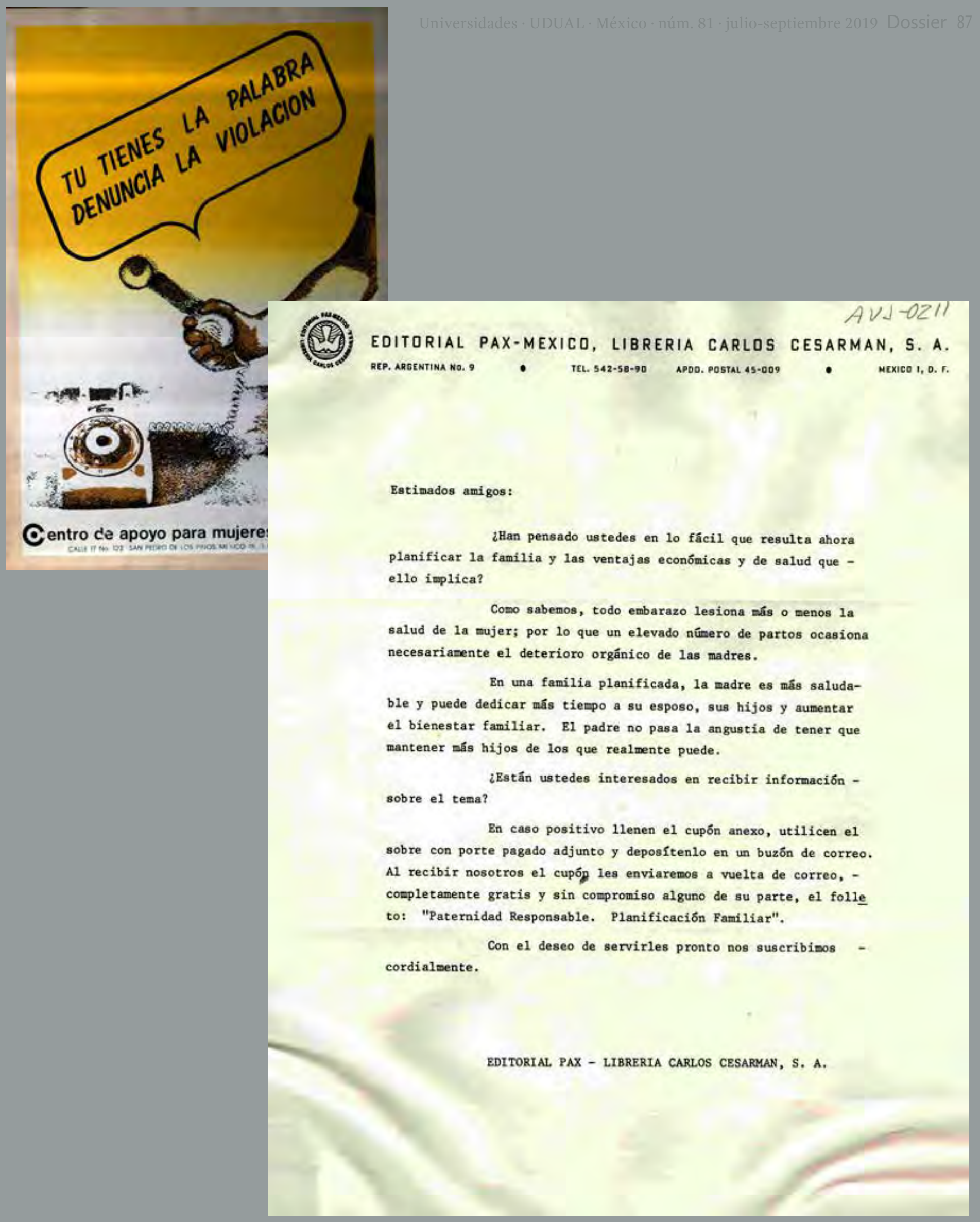

